\title{
Peningkatan Minat Kewirausahaan Berbasis Komunitas Pada Masyarakat Desa Sapolohe Kecamatan Bontobahari Bulukumba
}

\author{
${ }^{1}$ Muhammad Hidayat, ${ }^{2}$ Fitriani Latief dan 3 Nur Hidayah \\ ${ }^{1}$ STIE Nobel Indonesia Makassar, hidayat@stienobel-indonesia.ac.id \\ ${ }^{2}$ STIE Nobel Indonesia Makassar, fitri@ stienobel-indonesia.ac.id \\ ${ }^{3}$ STIE Nobel Indonesia Makassar, nurhidayah@stienobel-indonesia.ac.id
}

\section{Article history}

Received: 12 Agustus 2021

Revised: 28 September 2021

Accepted: 04 Oktober 2021

\section{Corresponding}

Author:

Muhammad Hidayat

STIE Nobel, Indonesia

Email: hidayat@stienobelindonesia.ac.id

\begin{abstract}
Abstrak
Tujuan Pengabdian pada Masyarakat ini adalah untuk meningkatkan minat kewirausahaan masyarakat Desa Sapolohe berbasis pada komunitas yang ada pada masyarakat, komunitas yang disasar dalam pelaksanaan Pengabdian ini adalah komunitas pedagang Komunitas Petani dan Komunitas Nelayan yang berada pada Desa Sapolohe Kecamatan Bontobahari Kabupaten Bulukumba. Metode yang digunakan adalah seminar, diskusi dan workshop, melalui kegiatan yang dilakukan telah mampu meningkatkan kesadaran masyarakat dalam berwirausaha dengan menggunakan komunitas yang ada. Dukungan yang diberikan oleh Kepala desa Sapolohe semakin mendukung semangat masyarakat untuk meningkatkan kewirausaannya dengan cara bergotong royong sesuai komunitas yang ada di Desa tersebut.

Kata kunci - Kewirausahaan, Komunitas usaha.

\section{Abstract}

The purpose of this Community Service is to increase the entrepreneurial interest of the people of Sapolohe Village, based on the community, the communities targeted in the implementation of this Service are the merchant community, the Farmer Community and the Fisherman Community located in Sapolohe Village, Bontobahari District, Bulukumba Regency. The methods used are seminars, discussions and workshops. Through the activities carried out, it has been able to increase public awareness in entrepreneurship by using the existing community. The support provided by the Sapolohe village head further supports the spirit of the community to increase their entrepreneurship by working together according to the community in the village.

Key Word : Entrepreneurship, Business Community
\end{abstract}

\section{PENDAHULUAN}

Sapolohe adalah salah satu kelurahan yang ada di Kecamatan Bonto Bahari Kabupaten Bulukumba. Kelurahan Sapolohe ini terdiri dari tiga lingkungan yaitu lingkungan Pasaraya Lama, Pasaraya Baru dan Sapolohe. Kelurahan Sapolohe terletak pada bagian Barat dalam wilayah Kecamatan Bonto Bahari. Jarak Kelurahan Sapolohe ke kota Bulukumba kurang lebih 25 (Dua Puluh Lima) kilometer dan waktu tempuh kurang lebih 1 (satu) jam. Perjalanan menuju ke kota Bulukumba dapat ditempuh dengan menggunakan kendaraan roda dua ataupun roda empat.

Berdasar pada demografi Desa Sapolohe maka membentuk tiga kekuatan ekonomi desa yaitu pertanian, perdagangan dan Nelayan. Meskipun dapat diidentifikasi tiga kegiatan utama perekonomian masyarakat desa namun saat ini mereka beraktivitas seperti biasa dan masih tergolong sebagai kegiatan yang dilakukan secara individual, belum terdapat adanya kelompok usaha yang bergerak dibidang yang sama meskipun diantara mereka sebenarnya memiliki kegiatan yang sama hal inilah yang kemudian menjadikan perekonomian Desa Sapolohe masih berjalan apa adanya dan dilaukan secara tradisional.

Dari kegigihan masyarakat dalam berwirausaha sesungguhnya dapat menjadi satu kekutana ekonomi yang cukup tangguh terlebih lagi jika kegiatan tersebut dapat dikelola secara professional dan modern salah satunya adalah 
membentuk kekuatan usaha dengan berbasis pada komunitas sehingga dengan komunitas tersebut masayarakat akan memiliki daya saing yang cukup baik terutama dalam menghadapi persaingan serta permasalaan fluktuasi harga yang kadang masih menjadi permasalahan karena beroperasinya tengkulak yang berhubungan langsung dengan masayarakat secara individu sehingga harga dapat dimainkan begitu saja sesuai dengan kesepakatan transaksi antara masayarakat dengan tengkulak.

Praktik tengkulak tersebut tentunya akan dapat diatasi dengan baik jika ada komunitas yag kemudian memiliki kekuatan dalam pelaksanaan transaksi perdagangan salah satunya dalam menentukan harga di tingkat petani, pedagang maupun nelayan.

Kekuatan usaha masyarakat tentunya juga akan sangat bergantung dari bagaimana pengelolaan bisnis, pengelolaan yang baik dengan berorientasi pada kualitas akan menjamin bisnis yang dilaksanakan semakin berkembang dan mampu bertahan dengan berbagai tantangan yang begitu dinamis saat ini dan begitu pula sebaliknya pengelolaan bisnis yang tidak tepat dan orientasi pada kepuasan konsumen yang lemah tentu akan sangat mempengaruhi bisnis tersebut bahkan pada titik terendah bisnis yang tidak mampu berorientasi pada pelanggan pasti akan hilang tertinggal permasalahan yang terjadi di Desa Sapolohe terkait dengan hal tersebut masih sangat lemah usaha yang dijalankan masih bersifat apa adanya dan sangat tradisional sehingga hal tersebut masih perlu untuk diperhatikan pendampingan kewirausahaan menjadi kegiatan yang sangat penting untuk dilakukan dengan harapan masyarakat desa Sapolohe akan dapat berusaha dengan baik dan mampu meningkatkan perekonomiannya di masa masa yang akan datang

Penigkatan perekonomian masyarakat merupakan program pemerintah yang sangat penting sebagai perwujudan dari tujuan pembangunan Nasional upaya-upaya untuk memberikan penguatan perekonomian pada masyarakat telah dilakukan oleh pemerintah salah satu perwujudan dari upaya tersebut adalah Pemberlakuan otonomi daerah yang bersamaan dengan terjadinya krisis ekonomi nasional dan global telah menambah kompleksitas permasalahan yang dihadapi oleh pemerintah pusat maupun pemerintah daerah. Dengan program otonomi daerah, pendekatan pembangunan ekonomi lokal (local economic development) selayaknya diarahkan pada peningkatan dan pemanfaatan unsur- unsur lokal (indigenous) (Mutakin \& Ridwan, 2020); (Ramadhani, 2020) yang mencakup sumberdaya alam, sumberdaya manusia, sosio kultural, dan lokasi strategis pembangunan daerah. Dengan pendekatan ini diharapkan daerah mampu meningkatkan kesejahteraan masyarakatnya secara mandiri didasarkan pada keuntungan kompetitif dan keuntungan komparatif. (Asrindah, 2020) Dalam pelaksanaannya kegiatan usaha berbasis komunitas juga akan meningkatkan kebersamaan komunitas untuk menghadapi berbagai kendala bisnis yang memang seharusnya dihadapi secara bersamasama (Handoko 2013)

Berangkat dari latar belakang tersebut pengabdian masyarakat ini diarahkan untuk dua hal penting dalam memberikan pendampingan penguatan perekonomian masayarakat desa Sapolohe yaitu (1) peningkatan kapasistas kewirausahaan berbasis komunitas dengan mempertimbangkan untuk melakukan penigkatan dan pemanfaatan unsur unsur-unsurlokal (indigenous) yaitu usaha-usaha yang massif dilakukan oleh masayarakat dan (2) untuk meningkatkan kapasistas kewirausahaan sehingga usaha yang dijalankan memiliki daya saing yag kana menjamin kompetitiveness usaha dan sustainability usaha yang dimiliki oleh masyarakat.

\section{METODE}

Metode yang digunakan dalam kegiatan pengabdian pada Masyarakat ini adalah :

1. Seminar Kewirausahaan

Metode Seminar ini di gunakan untuk memberikan gambaran dengan lebih detil tentang pentingnya pengembangan kewirausahaan dalam menghadapi perkembangan bisnis baik secara regional nasional maupun global, dalam seminar ini juga dibahasa tentang pentingnya pembentukan komunitas usaha dan manfaatnya dalam pengelolaan serta pengembangan bisnis begitupyula manfaat komunitas usaha dalam menghadapi persaigan maupun kepentingan kelompok tertentu yang akan berimbas pada bisnis yang digelutiya

\section{Diskusi}

Diskusi ini dilakukan untuk mengembangkan isyu-isyu yang sudah dilontarkan dalam seminar, diskusi juga untuk meneksplorasi permasalahan-permasalahan yang dihadapi 
oleh masyarakat dalam berusaha serta untuk memberikan solusi-solusi yang dapat digunakan oleh masayarakat dalam menghadapi permasalahan-permasalahan yang dihadapinya

3. Workshop

Workshop adalah praktek-praktek kewirausahaan yang dilaksanakan pada saat pelaksanaan kegiatan seperti praktek penyususnan laporan keungan, praktek teknik wrapup (pengemasan) serta praktek pembuatan media-promosi on line dengan menggunakan sosial media

Materi seminar serta diskusi yang diajukan berbasis pada permasalahan yang berkaitan dengan pokok analisis permasalahan yang akan diteliti yaitu tentang jenis jenis usaha yang menjadi kegiatan masyarakat sehingga kegiatan kegiatan usaha tersebut dapat dikelompokkan dalam komunitas-komunitas usaha yang secara sepesific dapat dijadikan sebagai komunitas usaha yang dapat dikembangkan .

Dalam Pelaksanaan Seminar maupun diskusi Peserta diberikan pengetahuan dan pemahaman tentang pentingnya usaha berbasis komunitas dan manfaat-manfaat yang bisa diambil melalui komunitas usaha yang solid. Peserta juga dibekali dengan pengetahuan terkait dengan strategi pengelolaan bisnis, strategi pemasaran serta penguatan melalui motivasi untuk terus berupaya meningkatkan kapasitas usahanya melalui peningkatan kualitas. Dalam pelaksaaan PKM ini juga melibatkan sejumlah mahasiswa STIE Nobel Indonesia yang berpartisipasi untuk menyalurkan informasi sosialisasi kepada masyarakat di wilayah PKM.

Pelaksanaan pengabdian dilakukan melalui tahapan-tahapan kegiatan sebagai berikut:

1. Identifikasi masalah dan potensi

a. Jenis-jenis usaha yang umum dilakukan oleh Masyarakat.

b. Permasalahan yang dihadapi oleh Masyarakat dalam berusaha

1. Masalah pelaksanaan Produksi.

2. Masalahn penambahan nilai pada Produksi.

3. Masalah pemasaran produksi.

2. Kesiapan Sumber Daya Manusia
a. Observasi
b. Wawancara
c. Analisa Data

4. Penentuan Jadwal Kegiatan
5. Persiapan Perlengkapan Kegiatan

6. Pelaksanaan Kegiatan

\section{HASIL DAN PEMBAHASAN}

Kegiatan pendampingan untuk meningkatkan kapsitas wirausaha berbasis komunitas pada Desa Sapolohe Kecamatan Bontobahari Kabupaten Bulukumba telah diadakan pada 15 Februari 2021 hingga 17 Februari 2021 yang berlangsung di aula desa setempat pengabdian ini dilakukan oleh pengabdi beserta Tim dan juga dibantu oleh Mahasiswa.

Target kegiatan pendampingan kepada Masyarakat ini adalah masyarakat pelaku usaha di desa Sapolohe Kecamatan Bontobahari Kabupaten Bulukumba. Tujuan utama pendampingan ini adalah untuk menyampaikan pemahaman terkait dengan permasalahan peningkatan kapasitas usaha ang dapat dikembangkan melalui pengelompokan pelaku usaha yang disesuaikan dengan jenis usaha yang sama sehingga dapat dimunculkan usaha-usaha berbasis komunitas usaha.

Tim Pengabdian Pada Masyarakat ini telah dilaksanakan oleh tim pelaksana Pengabdian Kepada Masyarakat yaitu : Dr.H.Muhammad Hidayat,S.E.,M.M, Fitrianie Latief, S.P., M.M. dan Nur Hidayah, S.E., M.Si. Pelaksanaan Pengabdian diatur dengan komposisi sebagai berikut : Dr.H.Muhamad Hidayat,S.E., M.M sebagai Ketua TIM sekaligus sebagai Pembicara dalam Seminar Kewirausahaan, Fitrianie Latief yang bertindak sebagai Moderatur baik pada Seminar maupun pada sesi Diskusi dan Nur Hidayah bertindak selaku pembicara dengan materik khusus yaitu peningkatan pemahaman para pelaku usaha desa dalam menyusun, mencatat dan menyiapkan laporan keuangan hal ini merupakan factor yang sangat penting mengingat selama ini para pelaku usaha tidak pernah melakukan pencatatan keuangannya semua yransaksi yang dilaukan dilaksanakan apa adanya dengan cara-cara tradisional tanpa pencatatan dan tanpa pelaporan. Sementara permasalahan keuangan dan pengelolaannya menjadi hal yang sangat untuk diketahui oleh para pelaku usaha agar mereka dapat mendeteksi hasil kegiatan usahanya melalui lapoan keuangan dengan pemahaman atas lapporan keuangan masyarakat akan mengetahui efektivitas serta kinerja usahanya. 


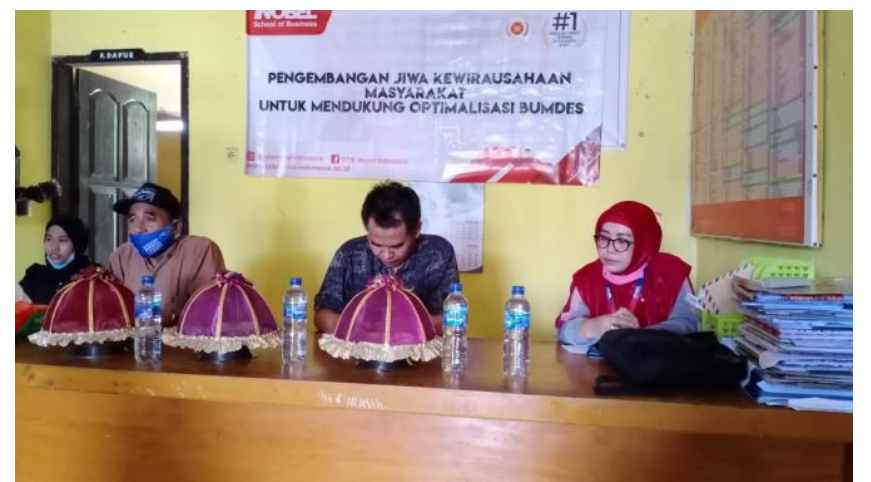

Gambar 1. Salah satu Narasumber Saat Memaparkan Materi

Pelaksanaan kegiatan ini melibatkan masyarakat Desa Sapolohe beserta perangkat Desa banyaknya peserta yang hadir menjadikan kegiatan seminar menjadi semakin hidup. Hal ini terlihat dari banyaknya pertanyaan peserta yang kemudian menjadi topik diskusi yang sangat menarik dan bermanfaat untuk mengeksplorasi permasalahan kewirausahaan yang ada di Desa Sapolohe. Dari seluruh rangkaian kegiatan beberapa hal yang kemudian mengemuka adalah permasalahan tidak adanya badan atau organisasi yang menaungi para pelaku usaha semisal koperasi atau sejenisnya sehingga masayrakat dapat terarah ketika melakukan kegiatan usahanya mereka berharap adanya kelompok yang dapat menyatukan mereka sehingga ketika mereka mendapatkan permasalahan mereka tidak merasa sendiri dan tidak dapat mencari solusi.

Munculya perlunya kelompok usaha dalam seminar maupun diskusi memang sengaja diarahkan oleh TIM Pengabdi terutama dari para pembicara tentang pentingnya menumbuhkan kelompok kelompok usaha yang solid sehingga dengan kelompok usaha tersebut para pelaku usaha dapat saling bersinergi bekerjasama dalam banyak hal misalnya bagi para petani mereka bisa biersinergi dalam masalah pengadaan pupuk karena semakin banyak pupuk yang didatangkan harga pupuk tersebut akan semakin murah berbeda dengan apabila pupuk itu didatangkan sendiri oleh petani secara perorangan karena pembelian perseorangan biasanya dalam volume terbatas maka hal tersebut dapat mempengaruhi harga. Selain itu melalui komunitas usaha distribusi penjualan menjadi semakin baik dan dapat meningkatkan daya saing terutama berkaitan dengan harga dengan adanya komunitas usaha terutama di bidang pertanian dan nelayan komunitas dapat menentukan harga jual yang lebih bersaing dibanding dengan harga yang dibuat secara pribadi oleh orang perorang yang kemudian rentan terhadap praktek tengkulak yang terkadang merugikan petani
Dalam materi seminar juga dibahas tentang manfaat yang dapat dipetik dari timbulnya komunitas usaha, melalui komunitas mereka dapat meningkatkan kapasias kewirausahaannya dengan saling bertukar pikiran dan berdiskusi sehingga mereka dapat mengambil terobosanterobosan dalam bingkai kretivitas dan inovasi

Para pelaku usaha yang datang menghadiri acara pengabdian, setelah mengikuti serangkaian seminar dan diskusi mereka mulai terbuka pola pikirmya untuk mengembangkan usaha dengan cara membentuk kelompok kelompok usaha berbasis komunitas bahkan di dalam diskusi mereka mulai memberikan pandangan-pandangan terkait apa yang sebaiknya dilakukan dan bagaimana menyikapi permasalahan yang dihadapi dalam menjalankan sebuah bisnis

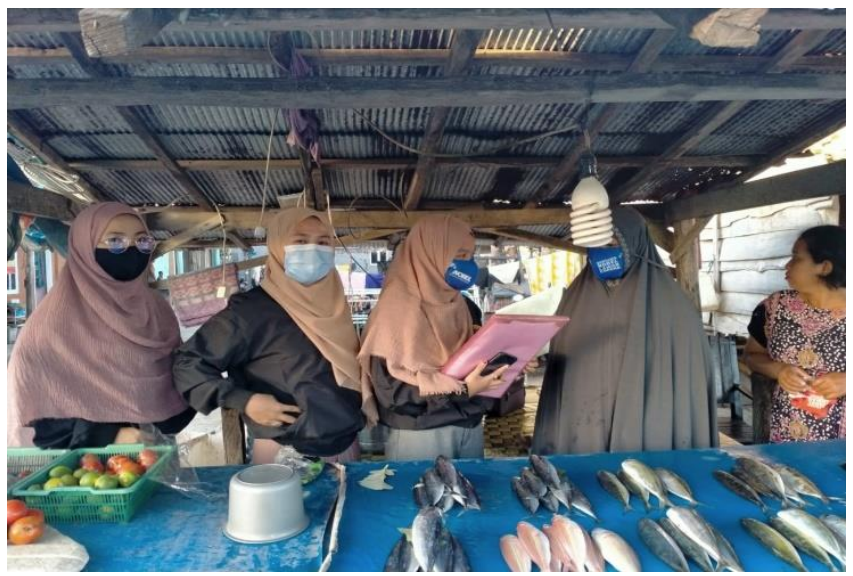

Gambar 2. Observasi Kegiatan Kewirausahaan Masyarakat

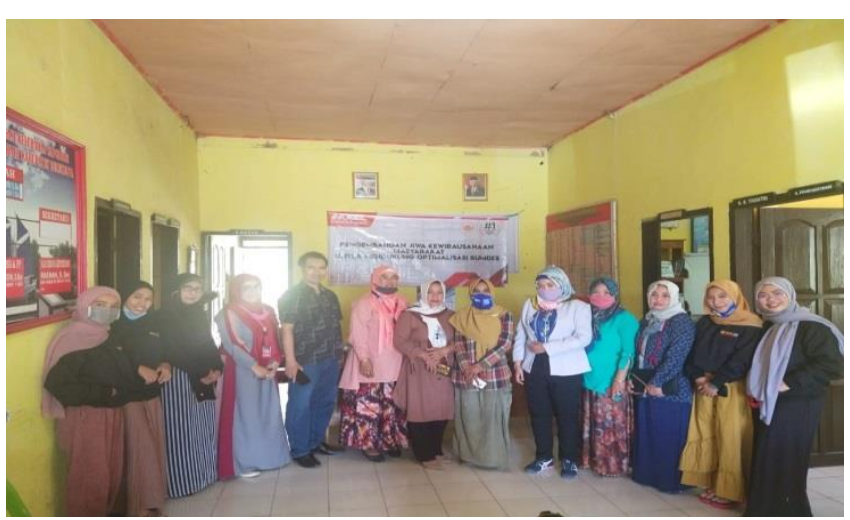

Gambar 3 Bersama Para Pelaku Usaha di Desa Sapolohe

Hasil pelaksanaan kegiatan Pengabdian Pada Masyarakat secara keseluruhan dapat dilihat dari beberapa hasil berikut ini :

1. Tercapainya Target sasaran Peserta

Sasaran peserta yang menjadi target dalam pengabdian ini adalah seluruh koponen masyarakat dengan jenis usaha yang dapat dikumpulkan dalam sebuah komunitas usaha informasi awal atas jenis-jenis usaha yang 
dikerjakan oleh masyarakat yang menjadi kecirian pada desa Sapolohe ada tiga jenis usaha yaitu Pertanian, Perdagangan dan Nelayan dengan demikian target peserta yang diharapkan dalam pengabdian ini adalah masyarakat yang memiliki kegiatan usaha pada tiga bidang tersebut sasaran ini terpenuhi yang ditunjukkan dari hasil pengumpulan data peserta yang memang memiliki kegiatan utama bertani, berdagang dan nelayan

2. Ketercapaian Tujuan

Tujuan dari pengabdian ini adalah untuk mengembangkan kapasitas usaha yang berbasis pada komunitas berangkat dari tema ini maka tujuan utama dari pelaksanaan pengabdian ini adalah membentuk komunitas-komuntas usaha yang nantinya akan menjadi kelompok komunitas usaha sebagai cikal bakal untuk mewujudkan komunitas itu menjadi organisasi yang lebih baik dengan sistem manajemen yang modern sehinga komunitas usaha tersebut dapat beroperasi dan bersaing secara professional dalam menghadapi dinamika dunia bisnis. Melalui pengabdian ini telah terbentuk komunitas usaha yaitu komunitas usaha tani, komunitas usaha perdagangan dan komunitas nelayan

Selain pembentukan komunitas usaha, pengabdian pada masyarakat ini juga melaukan serangkain seminar untuk meningkatkan kapasitas kewirausahaan masyarakat, dalam seminar telah disampaikan bagaimana meningkatkan produksi bagaimana meningkatkan kulaitas dan bagaimana memasarkan produk dengan bantuan tekhnologi yang semakin marak dewasa ini. Hasil dari seminar tersebut telah menumbuhkan motivasi para peserta yang secara antusias mengikuti kegiatan workshop bagaimana melakukan promosi penjualan dengan menggunakan media on line bagaimana membuat konten yang menarik serta bagaimana berinovasi dalam membuat tampilan produk melalui inovasi packaging

Antusiame peserta juga menjadi salah satu bukti bahwa tujuan pengabdian pada masyarakat telah tercapai dengan baik

3. Ketercapaian Target Materi yang Direncanakan.

Materi yang disampaikan dalam seminar maupun diskusi adalah materi yang telah disiapkan sedemikian rupa Materi ini disusun setelah melalui observasi lapangan yang dilakukan untuk mengetahui apa yang menjadi permasalahan dalam usaha yang dikelola oleh masyarakat, termasuk kendalakendala serta ancaman dan peluang yang dihadapi denan informasi yang akurat tersebut maka materi seminar disusun agar apa yang dibicarakan memang betul betul permasalahan yang dihadapi dan dirasakan oleh Masyarakat, sehingga materi tersebut mudah dipahami dan dimengeti.

Respon dari peserta sangat baik yang kemudian mampu membuata seminar maupun diskusi dapat dilaksanakan secara interaktif dan focus pada saran yang memang telah ditargetkan oleh TIM Pengabdian pada Masyarakat

4. Kemampuan Peserta dalam Mengikuti Setiap Proses Kegiatan

Selama pelaksanaan seminar seperti yang telah disampaikan sebelumnya seluruh peserta terlibat aktif dan interaktif peserta dapat menyerap apa yang disampaikan pemateri hal ini dapat dilihat dari respon peserta yang ditunjukan dari pertanyaanpertanyaan yang disampaikan saat seminar dilaksanakan begitu pula respon tangggapam masukan dan sanggahan dari para pesert terlihat sangat antusiaa dalam pelaksanaan diskusi.

Dengan keterlibatan peserta secara aktif maka pelaksanaan Seminar dan diskusi menghsilkan simpulan yang efektif untuk dapat djadikan sebagai hasil pelaksanaan Pengabdian Pada Masyarakat untuk diterapkan dan ditindaklanjuti.

\section{KESIMPULAN DAN SARAN}

Kegiatan Pengabdian kepada Masyarakat yang dilaksanakan di Desa Sapolohe Kecamatan Bontobahari Kabupaten Bulukumba tekah dilaksanakan dengan melibatkan masyarakat melalui kegiatan seminar workshop dan diskusi dari seluruh kegiatan tersebut telah dirancang penyususnan kegiatan kewirausahaan berbasis komuitas dengan mempertimbangkan kegiatan perekonomian dan kewirausahaan yang umum dilakukan oleh masyarakat Desa Sapolohe Kecamatan Bontobahari Kabupaten Bulukumba yaitu

1. Kegiatan Pertanianan yang akan membentuk komunitas petani

2. Kegiatan Perdagangan yang akan membentuk komunitas pedagang dan 
3. Kegiatan nelayan yang akan membentuk komunitas Nelayan

Secara umum dapat disimpukan tujuan kegiatan pengabdian masyarakat yang dimaksudkan untuk membangun serta meningkatkan kewirausahaan masayarakat desa melalui penmbangunan bisnisdan kewirausahaan berbasis komunitas telah berjalan sesuai dengan yang diharapkan

Dari kesimpulan tentang kegiatan pengabdian pada masyarakat diatas, maka ada beberapa saran yang perlu untuk diperhatikan dalam melakukan kegiatan pengabdian pada masyarakat di masa yang akan datang antara lain:

1. Agar pelaksanaan kegiatan pengabdian dapat mencapai sasaran maka diperlukan untuk adanya kerjasama yang lebih erat sebagai tindak lanjut pendampingan kewirausahaan kepada masyarakat

Perlu pengembangan pengetahuan kewirausahaan yang lebih baik dengan cara terus eningkatkan pendidikan dan pengembagan melalui studi banding, benchmarking, best praktis agar para pelaku usaha dapat melihat serta menimba pengalaman dari kelompok-kelompm usaha berabsis komunitas di tempat yang lain untuk dikembangkan di daerahnya

2. Perlu mulai untuk melakukan terobosanterobosan yang innovative kreatif agar produk yang dihasilkan dapat terus berkembang dan dapat bersaing secara sehat dengan produk-produk sejenis sehingga bisnis dapat berkembang berkelanjutan dengan baik..

\section{DAFTAR PUSTAKA}

Abdul Malik \& Sungkowo Edy Mulyono (2017) Pengembangan Kewirausahaan Berbasis Potensi Lokal Melalui Pemberdayaan
Volume 1 Namar 1 Tahun 2021

Masyarakat. Journal Of Nonformal Education and Comunnity Empowerment.

Asriandah (2020). Strategi Pengembangan Usaha Konveksi Berbasis Komunitas (Studi kasus Bordir dan Konveksi Medan Denai). Jurnal Bisnis Corporate Vol 5 no 2

Didip Diandra (2019) Program Pengembangan Kewirausahaan Untuk Menciptakan Pelaku Usaha Sosial Yang Kompetitif $10^{\text {th }}$ Industrial Research Workshop and National Seminar

Imam Mutakin \& Taufik Ridwan. (2020) Strategi Pengembangan Usaha Berbasis Komunitas (Studi Kasus Konveksi Jack Taylordi Desa Liperna) Jurnal Indonesia Sosial Sains Vol 1 No 1 Juli 2020

Tiara Ramadhani (2020) Pemeberdayaan Masyarakat Berbasis Komunitas Melalui Usaha Mikro Kecil dan Menengah (UMKM) (Studi Kasus Kelompok Pembina Kritcu BaBe di Desa Batu Belubang. Resiprokal Vol 2 no 2 Desember 2020

Waluyo Handoko (2013). Strategi Penembangan Masyarakat (Community Development) Melalui Program Pengembanagn Koperasi dan UMKM Berbasis Kearifan Lokal. Jurnal Ilmu Politik Dan Pemerintahan Vol 1 No 2 Januari 2013

Riane Johnly Pio \& Johny Montolalu (2017) Studi Tentang Wirausaha Baru Berbasis Partisipasi Masyarakat Di Sulawesi Utara. Program Studi Administrasi Bisnis Fisip Unsrat 